\title{
Seasonal temperatures over Italy and their relationship with low-frequency atmospheric circulation patterns
}

\author{
Andrea Toreti • Franco Desiato • \\ Guido Fioravanti · Walter Perconti
}

Received: 18 December 2007 / Accepted: 28 May 2009 / Published online: 10 September 2009

(C) Springer Science + Business Media B.V. 2009

\begin{abstract}
An analysis of Italian seasonal temperatures from 1961 to 2006 was carried out, using homogenized data from 49 synoptic stations well distributed throughout Italy. The results show remarkable differences among seasons. Stationarity characterizes winter series, except for Northern Italy (where a warming trend from 1961 is identified); a positive trend over the entire period is recognized for spring series. Summer series are marked by a negative trend until 1981 and by a positive trend afterwards; finally, autumn series show a warming starting from 1970. The relationship between seasonal temperatures and four teleconnection patterns (North Atlantic Oscillation, East Atlantic Pattern, Scandinavian Pattern and Arctic Oscillation) influencing European climate was investigated through Spearman rank correlation and composites. Among the results, the strong linear correlation with the East Atlantic Pattern in all seasons but autumn is remarkable; moreover, the explained variance varies between $31.9 \%$ and $50.4 \%$ (leaving out autumn). Besides these four atmospheric patterns the role of other factors (e.g. soil moisture) is not dealt with, but their importance and the need for more investigation is pointed out.
\end{abstract}

\section{Introduction}

As outlined by the IPCC Fourth Assessment Report (IPCC 2007), the global warming of the climate system is unequivocal; the linear trend of Northern Hemisphere annual land temperature ranges from $0.072 \pm 0.026^{\circ} \mathrm{C}$ per decade (NCDC dataset; Smith and Reynolds 2005 ) to $0.089 \pm 0.025^{\circ} \mathrm{C}$ per decade (CRU dataset; Brohan

A. Toreti $(\bowtie) \cdot$ F. Desiato · G. Fioravanti · W. Perconti

Istituto Superiore per la Protezione e la Ricerca Ambientale (ISPRA),

Via Vitaliano Brancati 48, 00144 Rome, Italy

e-mail: andrea.toreti@isprambiente.it

A. Toreti

Oeschger Centre for Climate Change Research (OCCR) and Institute of Geography,

Climatology and Meteorology, University of Bern, Bern, Switzerland 
et al. 2006) in the period 1901-2005 (Trenberth et al. 2007); furthermore, the warming has characterized all seasons since 1979, despite some local exceptions. In this context, the relevance of more detailed regional and local analysis can be outlined, in order to be able to quantify the climate changes at the spatial scale required by adaptation strategies and actions and, at the same time, closer to the common perception of climate change effects.

At the European scale the European Environment Agency (EEA 2008) reports a warming trend of temperature (most in spring and summer; data from 1850 to 2007); with large changes in the south-western, central and north-eastern Europe. Moreover, Luterbacher et al. (2004), applying a linear trend, estimated a winter warming rate equal to $0.08 \pm 0.07^{\circ} \mathrm{C} /$ decade in the period $1901-2000$; the warmest winter period was recorded in the period 1989-1998. As for summer temperature during the twentieth century, these results show a warming trend until 1947, followed by a cooling trend until 1977. Then 'an exceptionally, strong, unprecedented warming' is observed, characterized by a rate of $0.7 \pm 0.2^{\circ} \mathrm{C} / \mathrm{decade}$.

In Italy the mean annual temperature series are characterised by a negative trend from 1961 to 1981 and a more enhanced positive trend afterwards (Toreti and Desiato 2008; Brunetti et al. 2006). In particular, Brunetti et al. (2006) analysed seasonal temperatures, showing a warming linear trend from 1865 to 2003 in all seasons $(1.1 \pm 0.2 \mathrm{~K} /$ century in winter and summer, $1.0 \pm 0.2 \mathrm{~K} /$ century in spring and $0.8 \pm 0.2 \mathrm{~K} /$ century in autumn).

These seasonal temperature changes have strong impacts, among the others, on human health, economy and agriculture (see for a complete overview: EEA 2008). High temperatures increase heat-related illness, as well as cardiovascular and respiratory disease. In Italy, during summer, an increase of $1^{\circ} \mathrm{C}$ in maximum apparent temperature determines a positive change in daily mortality rate between about $3 \%$ and 5\% (analyzed cities: Rome, Milan and Turin; period: 1990-2004; Baccini et al. 2008). Moreover, due to seasonal temperature changes, the geographical alteration of the distribution of insect vectors enhances the risk of infectious diseases. Concerning agriculture, as classified by Kostrowicki (1991) and stated by Maracchi et al. (2005), Mediterranean countries are in the so-called third zone, characterized by diverse patterns of agriculture, ranging from a marked oriented type with mainly typical crop cultivation (e.g. fruit trees) to considerable areas of traditional type. Therefore, temperature changes affect mainly the growing season length and the quality and composition of land. As reported by EEA (2008), in the period 19752007 the rate of change of crop growing season length in Central Italy is greater than 0.8 days/year, whereas in the south-east part of Italy (Puglia) values lower than -0.8 days/year were found.

Several works investigated the relationship between climate variables, like temperature and precipitation, and low frequency circulation patterns of the atmosphere (e.g. Xoplaki et al. 2003, 2004; Jones et al. 2003; Xoplaki 2002; Quadrelli et al. 2001; Wibig 1999; Thompson and Wallace 1998; Reddaway and Bigg 1996; Hurrell 1995). However, most of them focused on NAO and winter temperature/precipitation recorded in the Northern Hemisphere or in the Mediterranean area (Pires and Perdigão 2007; Cohen and Barlow 2005; Trigo et al. 2002; Pozo-Vázquez et al. 2001; Hurrell and Van Loon 1997), leaving out other seasons and circulation modes; because NAO exerts a strong influence on European climate, more pronounced in winter months. 
In this paper an analysis of seasonal temperatures over Italy from 1961 to 2006 is presented, in order to describe their relationship with main circulation modes characterizing the Northern Hemisphere and influencing European/Italian climate. Four teleconnection patterns were chosen for this purpose: North Atlantic Oscillation (NAO), East Atlantic Pattern (EA), Scandinavian Pattern (SCAN) and Arctic Oscillation (AO). The following section describes data, quality control and time series homogenization procedures; the third section shows the results of time series analysis on seasonal temperature series, and their relationship with atmospheric circulation patterns.

\section{Data and methods}

Temperature data were elaborated from a set of 49 synoptic stations well distributed over the Italian territory, belonging to Air Force Weather Service (Fig. 1 and Table 1). Raw data undergo two quality controls: a weak climatological control and a consistency control; the former checks if a value belongs to a physically reasonable range, while the latter makes an ad-hoc comparison between variables (for example maximum and minimum temperature, or temperature and dew-point temperature; Desiato et al. 2007). Then ten-daily, monthly and annual indicators are calculated

Fig. 1 Map of the 49 stations. The different colors are associated with the number of detected and corrected inhomogeneities. The different shapes gives information on the number of missing monthly values in each series

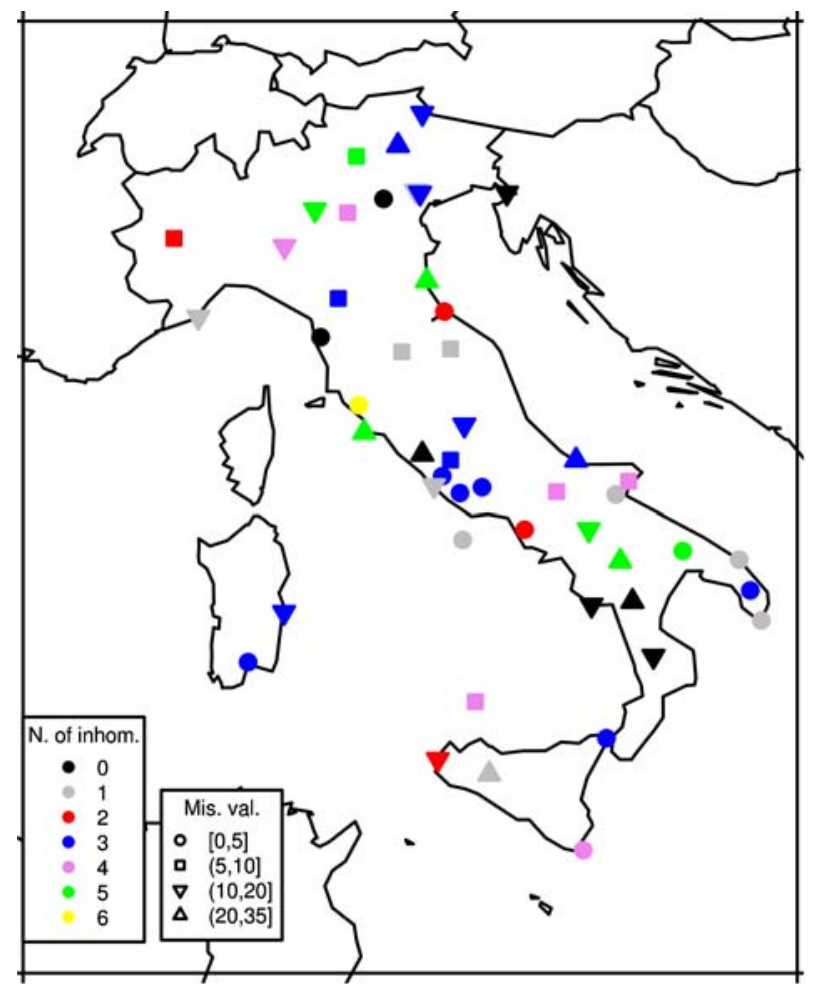


Table 1 List of the 49 stations

\begin{tabular}{|c|c|c|c|c|}
\hline Station & $\begin{array}{l}\text { WMO } \\
\text { CODE }\end{array}$ & Lat & Lon & $\begin{array}{l}\text { Ele } \\
(m)\end{array}$ \\
\hline$\overline{\text { Arezzo }}$ & 16172 & 43.48 & 11.85 & 248 \\
\hline Brescia/Ghedi & 16088 & 45.42 & 10.28 & 102 \\
\hline Brindisi & 16320 & 40.65 & 17.95 & 15 \\
\hline Cagliari/Elmas & 16560 & 39.25 & 9.07 & 4 \\
\hline Campobasso & 16252 & 41.57 & 14.65 & 793 \\
\hline Capo Bellavista & 16550 & 39.93 & 9.72 & 138 \\
\hline Capo Mele & 16153 & 43.95 & 8.17 & 220 \\
\hline Capo Palinuro & 16310 & 40.03 & 15.28 & 184 \\
\hline Cozzo Spadaro & 16480 & 36.68 & 15.13 & 46 \\
\hline Dobbiaco & 16033 & 46.74 & 12.22 & 1222 \\
\hline Foggia/Amendola & 16261 & 41.53 & 15.72 & 57 \\
\hline Frontone & 16179 & 43.52 & 12.73 & 570 \\
\hline Frosinone & 16244 & 41.63 & 13.30 & 180 \\
\hline Gioia del Colle & 16312 & 40.77 & 16.93 & 345 \\
\hline Grazzanise & 16253 & 41.06 & 14.07 & 9 \\
\hline Grosseto & 16206 & 42.75 & 11.07 & 5 \\
\hline Guidonia & 16234 & 42.00 & 12.73 & 88 \\
\hline Istrana & 16098 & 45.68 & 12.10 & 45 \\
\hline Latina & 16243 & 41.55 & 12.90 & 25 \\
\hline Latronico & 16316 & 40.08 & 16.02 & 888 \\
\hline Lecce & 16332 & 40.23 & 18.15 & 48 \\
\hline Messina & 16420 & 38.21 & 15.55 & 59 \\
\hline Monte Argentario & 16168 & 42.38 & 11.17 & 630 \\
\hline Monte Cimone & 16134 & 44.21 & 10.70 & 2165 \\
\hline Monte S.Angelo & 16258 & 41.71 & 15.95 & 838 \\
\hline Monte Scuro & 16344 & 39.33 & 16.40 & 1710 \\
\hline Monte Terminillo & 16219 & 42.48 & 12.98 & 1874 \\
\hline Paganella & 16022 & 46.15 & 11.03 & 2125 \\
\hline Passo Rolle & 16021 & 46.30 & 11.78 & 2004 \\
\hline Piacenza & 16084 & 44.92 & 9.73 & 134 \\
\hline Pisa/S. Giusto & 16158 & 43.68 & 10.38 & 2 \\
\hline Ponza & 16280 & 40.92 & 12.95 & 184 \\
\hline Potenza & 16300 & 40.63 & 15.80 & 823 \\
\hline Pratica di mare & 16245 & 41.65 & 12.43 & 6 \\
\hline Prizzi & 16434 & 37.72 & 13.43 & 1034 \\
\hline Punta Marina & 16146 & 44.45 & 12.30 & 2 \\
\hline Rimini & 16149 & 44.03 & 12.62 & 12 \\
\hline Roma/Ciampino & 16239 & 41.78 & 12.58 & 129 \\
\hline S. Maria di Leuca & 16360 & 39.82 & 18.35 & 104 \\
\hline Termoli & 16232 & 42.00 & 15.00 & 16 \\
\hline Torino/Bric della Croce & 16061 & 45.03 & 7.73 & 709 \\
\hline Trapani/Birgi & 16429 & 37.92 & 12.50 & 7 \\
\hline Trevico & 16263 & 41.06 & 15.23 & 1085 \\
\hline Treviso/S.Angelo & 16099 & 45.65 & 12.18 & 18 \\
\hline Trieste & 16110 & 45.65 & 13.75 & 8 \\
\hline Ustica & 16400 & 38.71 & 13.18 & 250 \\
\hline Verona/Villafranca & 16090 & 45.38 & 10.87 & 67 \\
\hline Vicenza & 16094 & 45.57 & 11.52 & 39 \\
\hline Vigna di Valle & 16224 & 42.08 & 12.22 & 262 \\
\hline
\end{tabular}


and checked through a statistical procedure based on interquartile range and spatial comparison (Baffo et al. 2005; Eischeid et al. 1995); outliers, which are recognized as wrong values, are discarded and do not contribute to the analysis.

In order to eliminate or at least reduce potential effects of non-climatic factors affecting climatic series, like relocation of stations or changes in observational practices, monthly temperature series were homogenized (Toreti and Desiato 2006), through the Standard Normal Homogeneity Test (Alexandersson and Moberg 1997). The reference series were constructed with at least three stations, and correlation coefficients were calculated using the first-difference time series, as suggested by Peterson and Easterling (1994). Furthermore, after the homogenization procedure, missing data in a series were reconstructed using the approach of a constant difference between the series and its reference series; due to the unavailability of corresponding reference values, a few monthly values in 1988 were estimated using a SARIMA model (Shumway and Stoffer 2000).

Finally, seasonal series were elaborated in terms of temperature anomalies with respect to the 1961-1990 reference period; the standard definition of meteorological seasons was applied: winter (December, January and February), spring (March, April and May), summer (June, July and August) and autumn (September, October and November). The series were calculated for the whole domain (Italy) and three sub-domains (Northern, Central and Southern Italy including Sicily and Sardinia islands).

As for atmospheric circulation patterns we used monthly indices provided by the NOAA Climate Prediction Center (www.cpc.ncep.noaa.gov), elaborated (except for AO index, constructed using monthly mean $1000 \mathrm{mb}$ height anomalies) from standardized monthly $500 \mathrm{mb}$ height anomalies through Rotated Principal Component Analysis (Barnston and Livezey 1987).

Among the teleconnection patterns over the Northern Hemisphere the most known and investigated is the North Atlantic Oscillation (NAO; see for example: Hurrell et al. 2003; Wanner et al. 2001; Hurrell 1995). It is a north-south pressure dipole with two centers located approximately over Greenland and Azores, subject to strong seasonal variations. Two kinds of indices were developed in order to describe the NAO. One is defined as the difference between the normalized sea level pressure between Lisbon, Portugal (or Ponta Delgada, Azores) and Stykkisholmur, Iceland; the other (as the NOAA index) is defined as the first leading mode carried out with a Rotated Principal Component Analysis of the $500 \mathrm{mb}$ height anomalies. The NAO index seasonal series are almost stationary, except the winter one characterized by a positive trend from 1961 to 2006.

The East Atlantic Pattern (Barnston and Livezey 1987) is the second leading mode and it resembles NAO, though there are remarkable differences. Indeed, it is a north-south dipole, with a center located near $55^{\circ} \mathrm{N}, 20-35^{\circ} \mathrm{W}$ and an opposite one over North Africa $\left(25-35^{\circ} \mathrm{N}, 0-10^{\circ} \mathrm{W}\right)$. EA seasonal series show a positive trend in winter and summer.

The Scandinavian Pattern (Eurasia pattern type 1 in Barnston and Livezey 1987) consists of a strong center located over Scandinavia, an opposite center in northwest China (weak in summer during its positive phase) and another one with opposite sign over an area spanning Spain and adjacent Atlantic/Mediterranean. Only summer 
series shows a pronounced positive trend from 1961 until 1978, while the following period (as the other seasonal series) is stationary.

Finally, the Arctic Oscillation (Thompson and Wallace 1998) has a centre of action located over the Arctic and an annular structure with opposite sign at midlatitudes. It resembles the pattern of NAO, but its dynamical interpretation is different (Wanner et al. 2001); however, the relationship between NAO and AO is still an open issue. AO index is constructed by projecting monthly mean $1,000 \mathrm{mb}$ height anomalies poleward of $20^{\circ} \mathrm{N}$ onto its loading pattern (leading mode of EOF analysis of monthly mean 1,000 mb height). Its seasonal series are stationary.

The evaluation of the series behaviour was performed in the so-called time domain. First of all, the stationarity was tested using two tests (with a $p$-value equal to 0.05): the well-known Mann-Kendall non parametric test (Sneyers 1990) and the test developed by Giraitis et al. (2006) (hereafter $G$ test). The former focuses only on monotonic trends, while the latter considers a wide class of deterministic trends (e.g. linear, polynomial) and unit root. Its test function is $T_{n}(\hat{d})=(q / n)^{-2 \hat{d}}\left(V_{n} / \hat{s}_{n, q}^{2}\right)$, where:

$V_{n}=n^{-2}\left[\sum_{k=1}^{n}\left(S_{k}^{*}\right)^{2}-n^{-1}\left(\sum_{k=1}^{n} S_{k}^{*}\right)^{2}\right], \quad S_{k}^{*}=\sum_{j=1}^{k}\left(X_{j}-\bar{X}_{n}\right), \quad \hat{s}_{n, q}^{2}=q^{-1} \sum_{i, j=1}^{q} \hat{\gamma}_{i-j}$,

and $n$ denotes the number of data, $X$ the series, $q$ a bandwidth (we perform the test twice, using $q$ equal to zero and one) and $\hat{\gamma}_{i-j}$ sample covariances; furthermore, the parameter $d$ was set equal to zero.

Since a monotonic linear trend cannot always represent a reliable choice in climatic series (Vogelsang and Franses 2005; Seidel and Lanzante 2004; Tomé and Miranda 2004), we carried out a change point analysis for non-stationary time series. For this purpose we applied two tests: the two phase regression (TPR; Lund and Reeves 2002) and the test developed by Bai and Perron (1998). When no change point was found we applied a linear regression method, estimating parameters with an Ordinary Least Square Estimation (OLS); otherwise, a sloped-steps model was applied:

$$
Y_{t}=D_{1} \alpha_{1}+D_{2} \alpha_{2}+D_{1} \beta_{1} t+D_{2} \beta_{2} t+X_{t}
$$

where $Y$ denotes the time series, $X$ the error term (iid), $D_{1}$ and $D_{2}$ two dummy variables-equal to 1 (zero) before (after) the change point and equal to 0 (one) after (before) the change point-and $\alpha_{i}, \beta_{i}$ the parameters estimated through an OLS.

Table 2 Results of trend analysis

\begin{tabular}{llllll}
\hline & Winter & Spring & Summer before & Summer after & $\begin{array}{l}\text { Autumn from } \\
\text { c.p. }\end{array}$ \\
\hline Italy & - & $0.025 \pm 0.0089$ & $-0.046 \pm 0.0236$ & $0.062 \pm 0.0182$ & $0.044 \pm 0.0106$ \\
North & $0.027 \pm 0.0111$ & - & $-0.039 \pm 0.0251$ & $0.064 \pm 0.0193$ & $0.041 \pm 0.0107$ \\
Centre & - & $0.023 \pm 0.0091$ & $-0.061 \pm 0.0283$ & $0.072 \pm 0.0191$ & $0.043 \pm 0.0116$ \\
South & - & $0.024 \pm 0.0237$ & $-0.045 \pm 0.023$ & $0.056 \pm 0.0178$ & $0.046 \pm 0.0112$ \\
\hline
\end{tabular}

Slope and standard error are expressed in ${ }^{\circ} \mathrm{C} /$ year 


\section{Results}

\subsection{Temperature series}

The seasonal series show a different behaviour for Italy and its three sub-areas; Table 2 summarizes all the results. Winter series (Fig. 2) do not show any evidence of non-stationarity, with the exception of Northern Italy where a weak trend signal was found: the Mann-Kendall test reports a $p$-value of 0.078 , while the $G$ test reveals the presence of a trend with a $p$-value of 0.05 ; no change point was found. Therefore, the application of a linear model gives a warming trend with a slope of $0.027^{\circ} \mathrm{C} /$ year.

With the exception of Northern Italy, in spring (see Fig. 3) a significant warming starting from 1961 (no change point was found) is detected, with slopes ranging from $0.023^{\circ} \mathrm{C} /$ year to $0.025^{\circ} \mathrm{C} /$ year (with $p$-values $\leq 0.01$ ). In Northern Italy both MannKendall and $G$ test give no stationarity, and TPR reveals a change point in 1987 (confirmed by Bai and Perron method); but the analysis of these two sub-periods gives no evidence of trend components, while a $t$-test shows that the two samples

Italy

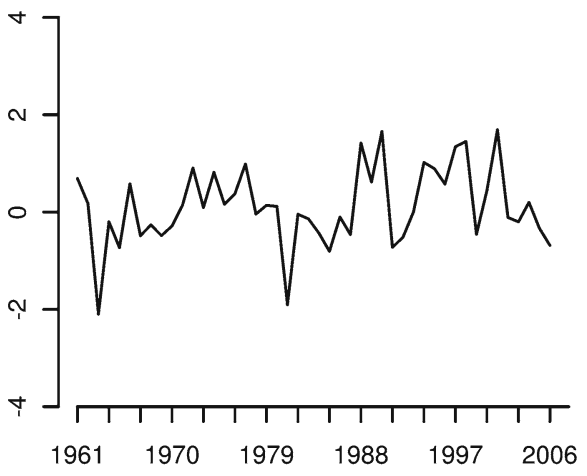

Centre

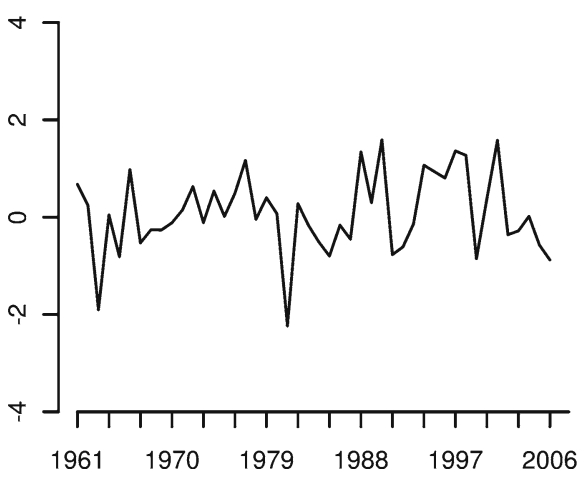

North
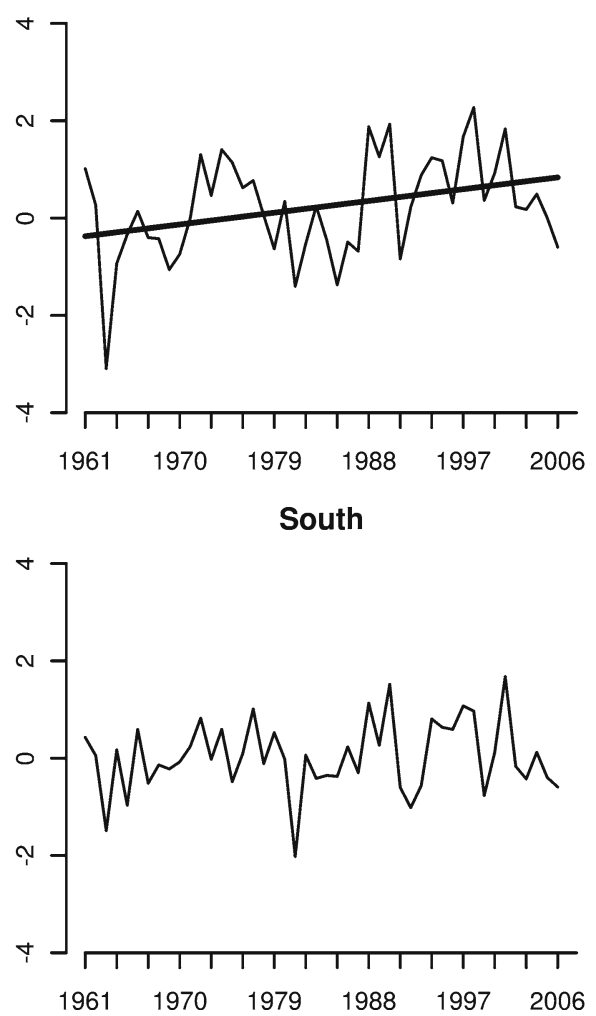

Fig. 2 Winter series for Italy and the three sub-areas (North, Centre and South). Anomalies are in ${ }^{\circ} \mathrm{C}$; thick lines represent trend 
Italy
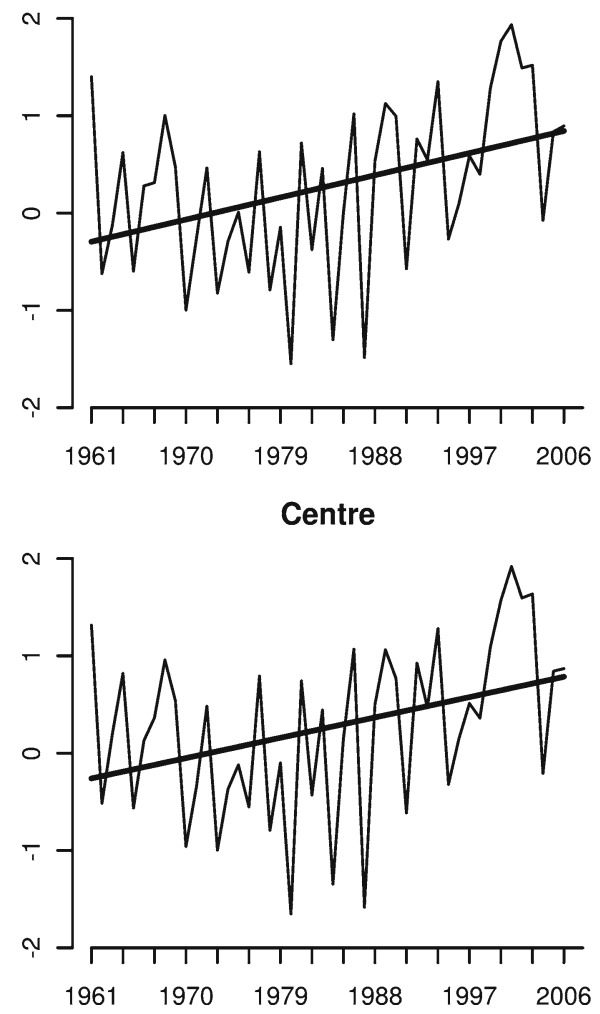

North
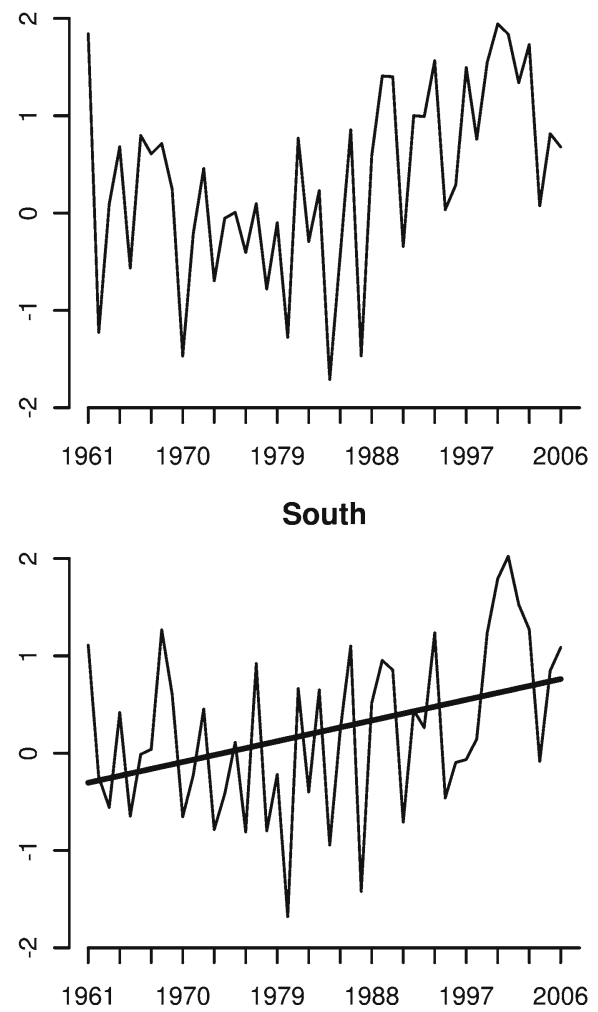

Fig. 3 Spring Series for Italy and the three sub-areas (North, Centre and South). Anomalies are in ${ }^{\circ} \mathrm{C}$; thick lines represent trend

have different means. It can be concluded that the signal reported by the MannKendall and $G$ tests is not due to the presence of a trend (monotonic or not), but to a sudden change of the mean.

Summer series (Fig. 4) show a common change point in 1981 (except for Central Italy, where the change point is in 1980); before 1981, a cooling phase was detected, with slopes ranging from -0.061 to $-0.039^{\circ} \mathrm{C} /$ year ( $p$-values from 0.04 to 0.1 ), while after 1981 more enhanced warming trends were detected, with slopes ranging from $0.056^{\circ} \mathrm{C} /$ year to $0.072^{\circ} \mathrm{C} /$ year ( $p$-values less than 0.01 ). The extreme mean temperature value recorded in 2003 deserves special attention.

No remarkable differences characterize autumn series (Fig. 5); after a stationary period until 1970, a significant warming trend is detected by all series. Estimated slopes ranges from $0.041^{\circ} \mathrm{C} /$ year to $0.046^{\circ} \mathrm{C} /$ year ( $p$-values less than 0.01 ).

\subsection{Teleconnection patterns}

We analyzed the correlation between the seasonal temperature series over Italy, both for the whole domain and its three sub-areas, and the seasonal series of the four teleconnection indices: NAO, EA, SCAN, AO. Table 3 illustrates such results. 


\section{Italy}

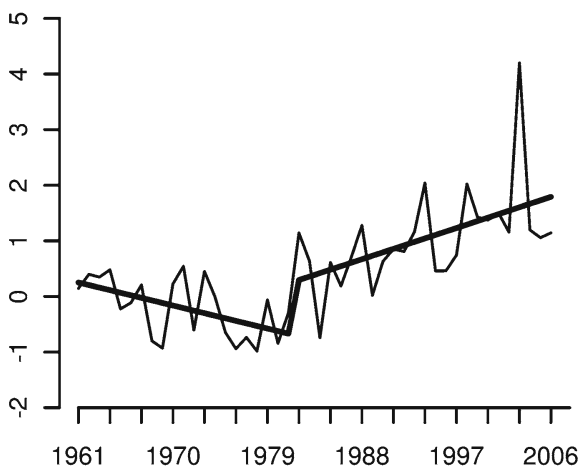

Centre

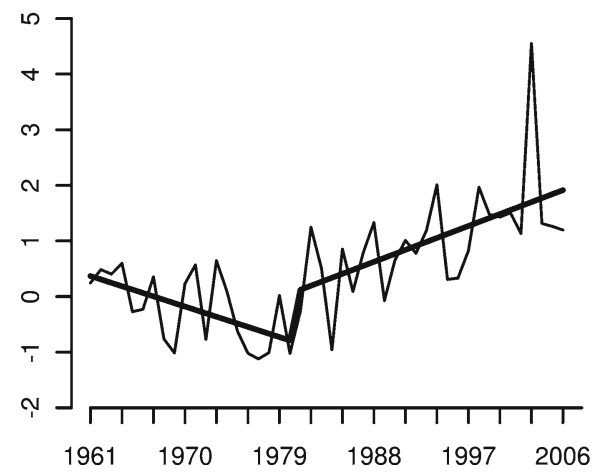

North

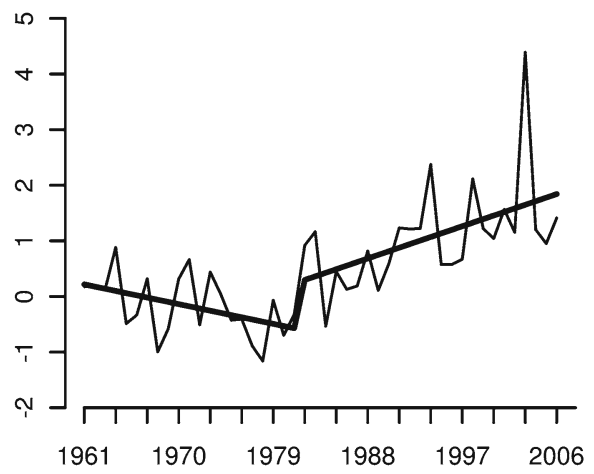

South

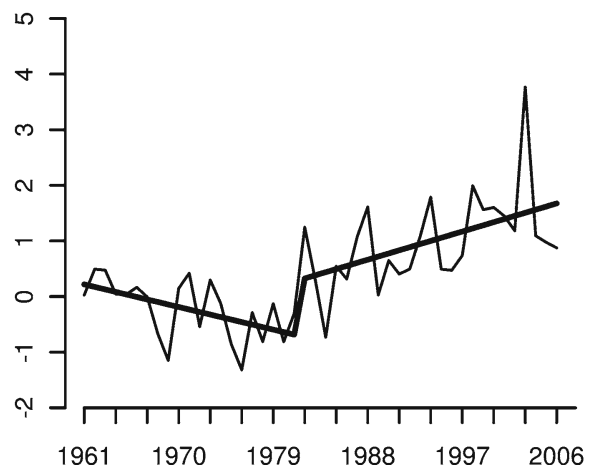

Fig. 4 Summer series for Italy and the three sub-areas (North, Centre and South). Anomalies are in ${ }^{\circ} \mathrm{C}$; thick lines represent trend

The coefficients were calculated using the Spearman Rank Correlation, applied to the detrended series. It is important to underline that lack of correlation (no significant correlation value) does not imply independence of two time series, but only the absence of simple linear relationship between them. As for NAO we did not find any significant correlation, except for Northern Italy in winter. This might indicate that more complex, non-linear relationship links temperatures with this pattern, as suggested for example by Pozo-Vázquez et al. (2001). Figure 6 shows the mean winter anomaly temperatures over Italy in 1995 and 2000, when a winter positive NAO appears (1.36 and 1.30, respectively). Differences between these two maps are evident, especially in Central and Southern Italy, even characterized by opposite temperature values in 2000; only in Northern Italy a consistent behaviour is observable. Again, this result could indicate a possible complex response of temperature over Central/Southern Italy to the same condition of the NAO. These results are in agreement with the correlation map between NAO and extended winter temperature over the Mediterranean basin, showed by Xoplaki (2002). She reports significant values (ranging from 0.18 to 0.5 ) in Northern Italy and non-significant correlation (absolute values less than 0.14 ) in Central/Southern Italy. 
Italy
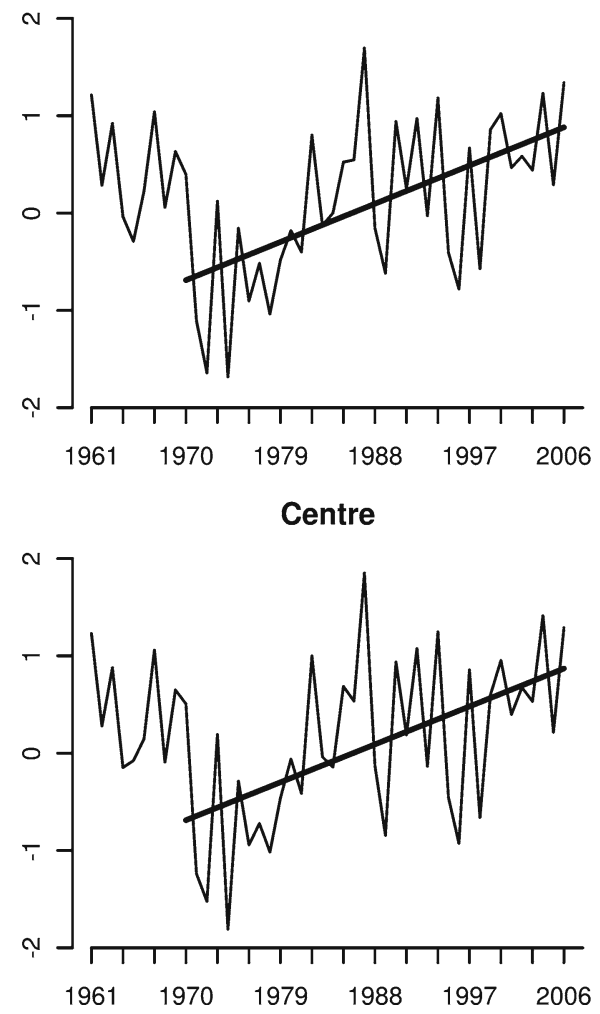

North
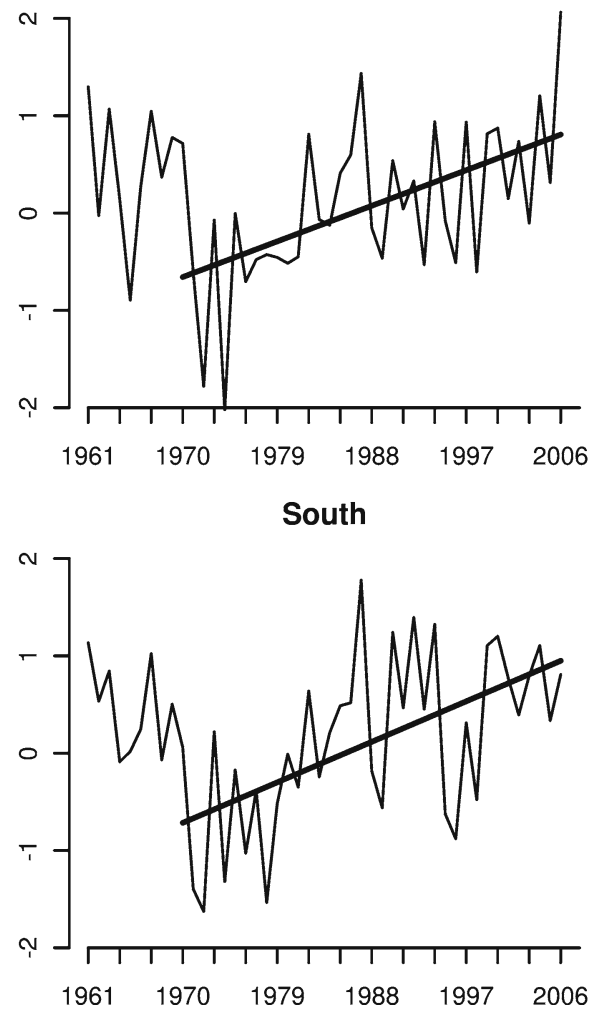

Fig. 5 Autumn series for Italy and the three sub-areas (North, Centre and South). Anomalies are in ${ }^{\circ} \mathrm{C}$; thick lines represent trend

The correlations with the East Atlantic pattern (a leading mode in all months) are significant in three seasons out of four (winter, spring and summer) and for all three sub-areas; this implies a more linear relationship between Italian temperature and EA, particularly in winter and spring. Composites of winter temperature anomalies with respect to positive and negative EA index (Fig. 7) provide a better description of the response to this pattern; as for composites we divided EA index in two classes (positive and negative); a further subdivision (extremely negative/negative, positive/extremely positive; with a threshold of \pm 0.5 ) gives poor results in terms of $t$ test: only a small subset of stations record significant differences (applying the $t$ test with a $p$-value of 0.05 ) among extremely negative and negative and positive and extremely positive composites. On the contrary, as for spring composites a subdivision into four subsets gives significant differences, as shown by composites for positive (values belong to $[0,0.5]$ ) and extremely positive $(\geq 0.5)$ in Fig. 8 . Furthermore, we can observe the strong anomalies recorded in Central Italy during years with extremely positive EA index. The negative and extremely negative classes do not separate as well, indeed no station gives significant differences between them. 
Table 3 Correlation coefficients

Italic denotes no-significant values $(95 \%$ level)

\begin{tabular}{lcccc}
\hline & Winter & Spring & Summer & Autumn \\
\hline NAO & & & & \\
Italy & 0.17 & 0.09 & 0 & 0.09 \\
North & 0.4 & 0.16 & 0.14 & 0.07 \\
Centre & 0.06 & 0.07 & 0 & 0.03 \\
South & -0.03 & 0 & -0.17 & 0.19 \\
EA & & & & \\
Italy & 0.52 & 0.55 & 0.4 & 0.27 \\
North & 0.36 & 0.41 & 0.31 & 0.25 \\
Centre & 0.57 & 0.56 & 0.36 & 0.26 \\
South & 0.57 & 0.55 & 0.44 & 0.18 \\
SCAN & & & & \\
Italy & -0.06 & -0.22 & -0.4 & -0.07 \\
North & -0.07 & -0.18 & -0.37 & -0.15 \\
Centre & 0 & -0.22 & -0.43 & -0.09 \\
South & 0.05 & -0.21 & -0.34 & 0.05 \\
AO & & & & \\
Italy & 0.11 & 0.46 & 0.03 & 0.28 \\
North & 0.31 & 0.46 & 0.22 & 0.35 \\
Centre & -0.02 & 0.46 & 0 & 0.23 \\
South & -0.14 & 0.39 & -0.15 & 0.25 \\
\hline
\end{tabular}

In summer we have an analogous situation, i.e. no difference between negative classes versus significant differences among positive and extremely positive. Figure 9 shows the small anomalies (close to zero) during years with positive EA index versus the very high values (always $>1^{\circ} \mathrm{C}$ ) during years with extremely positive indices.

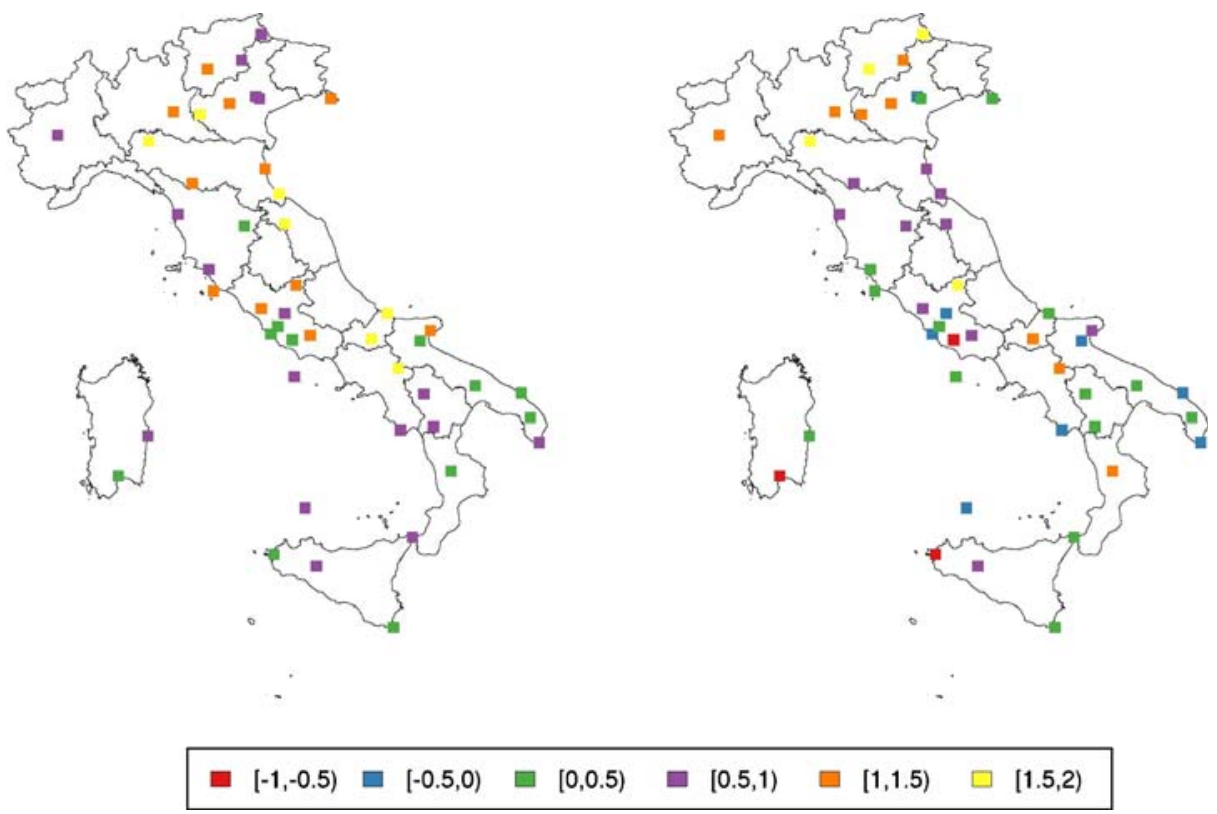

Fig. 6 Winter temperature anomalies in 1995 (left panel) and 2000 (right panel) 


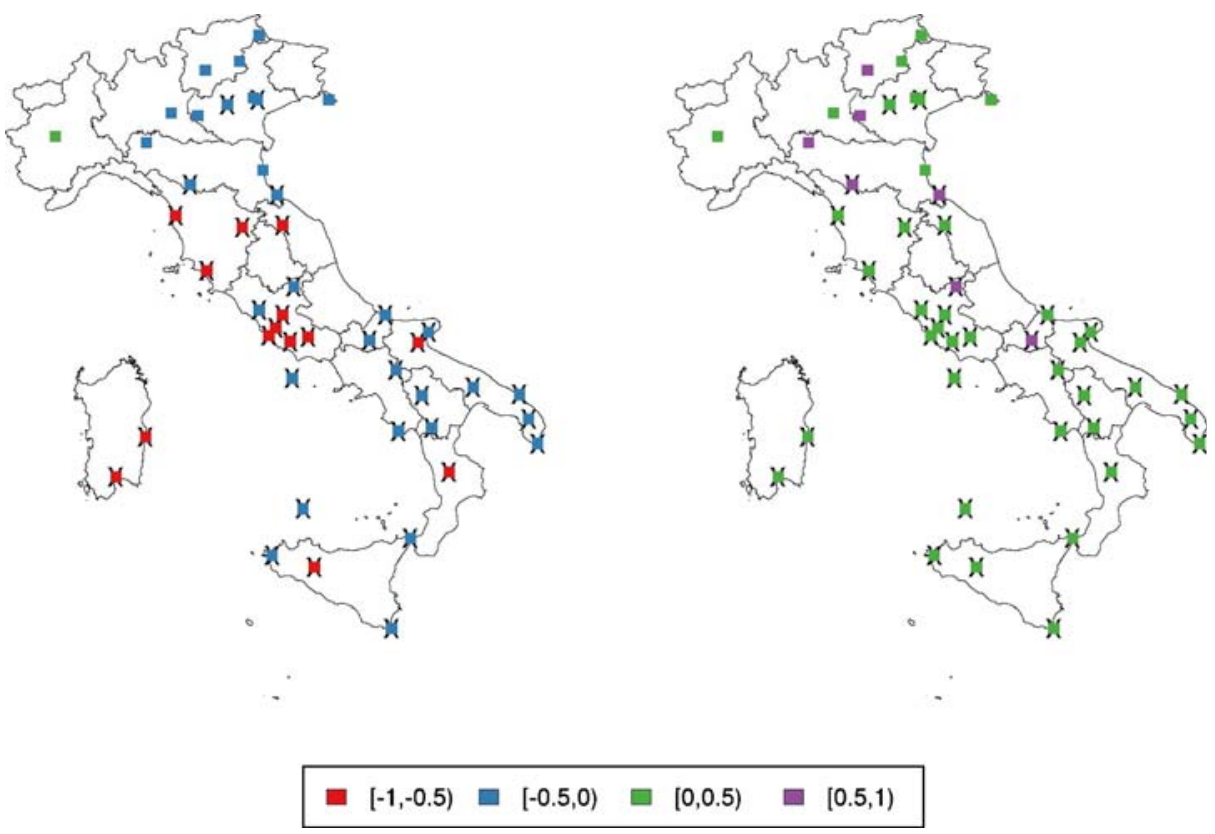

Fig. 7 Winter composites of temperature anomalies for EA indices positive (right panel) and negative (left panel). Crosses denote stations with significant differences
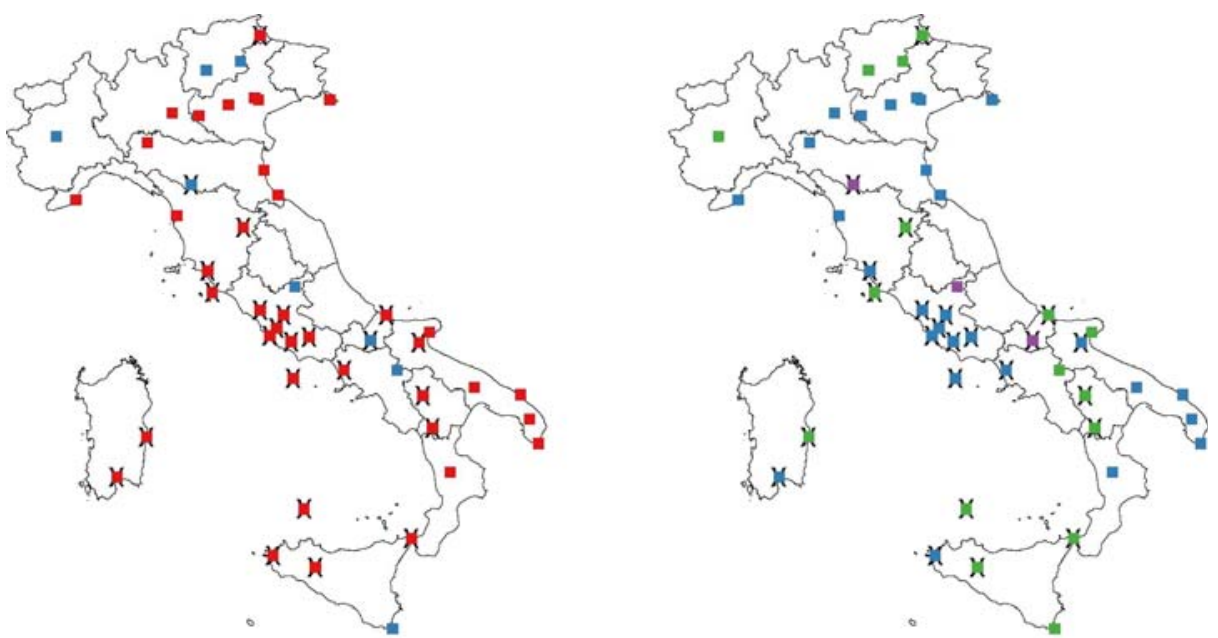

$[0,0.5)$

$[0.5,1)$

$[1,1.5)$

$[1.5,2)$

Fig. 8 Spring composites of temperature anomalies for EA indices positive-in $(0,0.5)$, left paneland extremely positive $\longrightarrow \geq 0.5$, right panel. Crosses denote stations with significant differences 


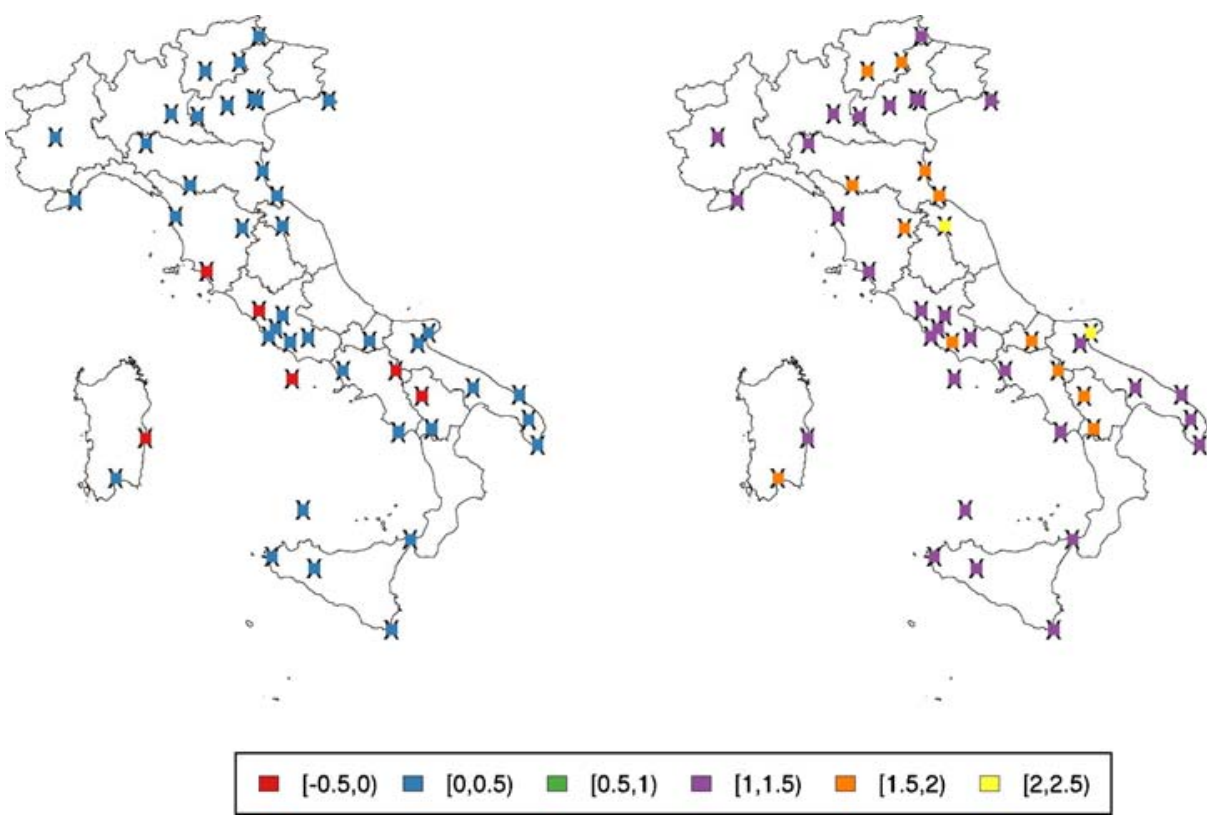

Fig. 9 Summer composites of temperature anomalies, for EA indices positive-in $(0,0.5)$, left panel - and extremely positive- $\geq 0.5$, right panel. Crosses denote stations with significant differences
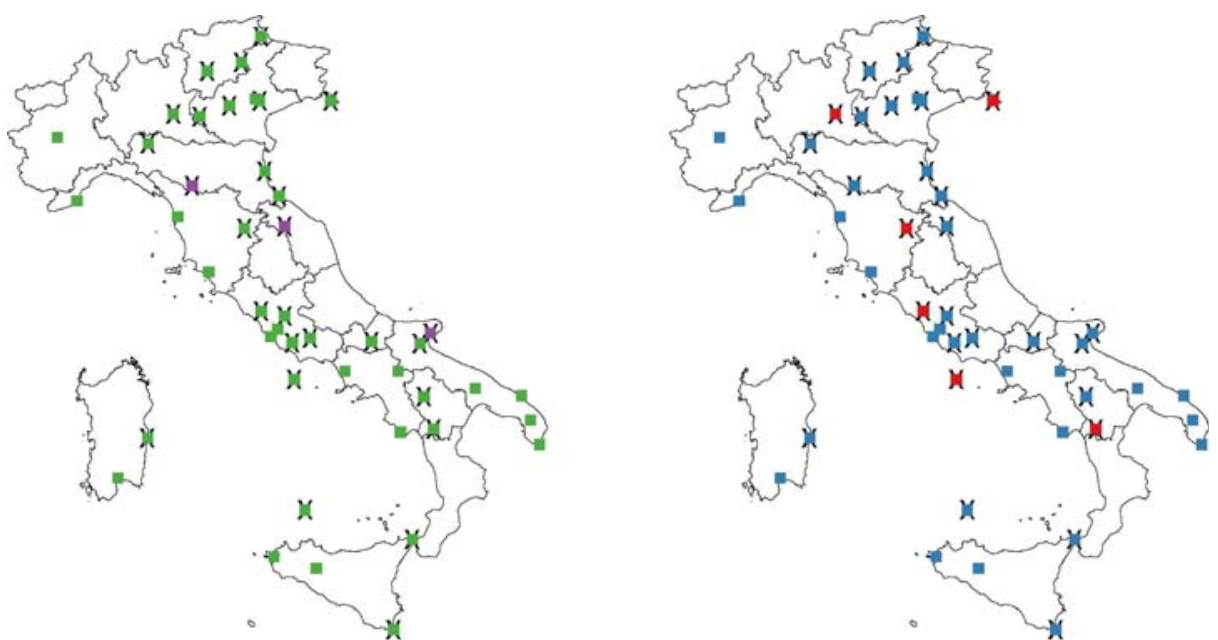

$$
[-0.5,0)
$$

$[0.5,1)$

Fig. 10 Summer composites of temperature anomalies for SCAN indices positive (right panel) and negative (left panel). Crosses denote stations with significant differences 


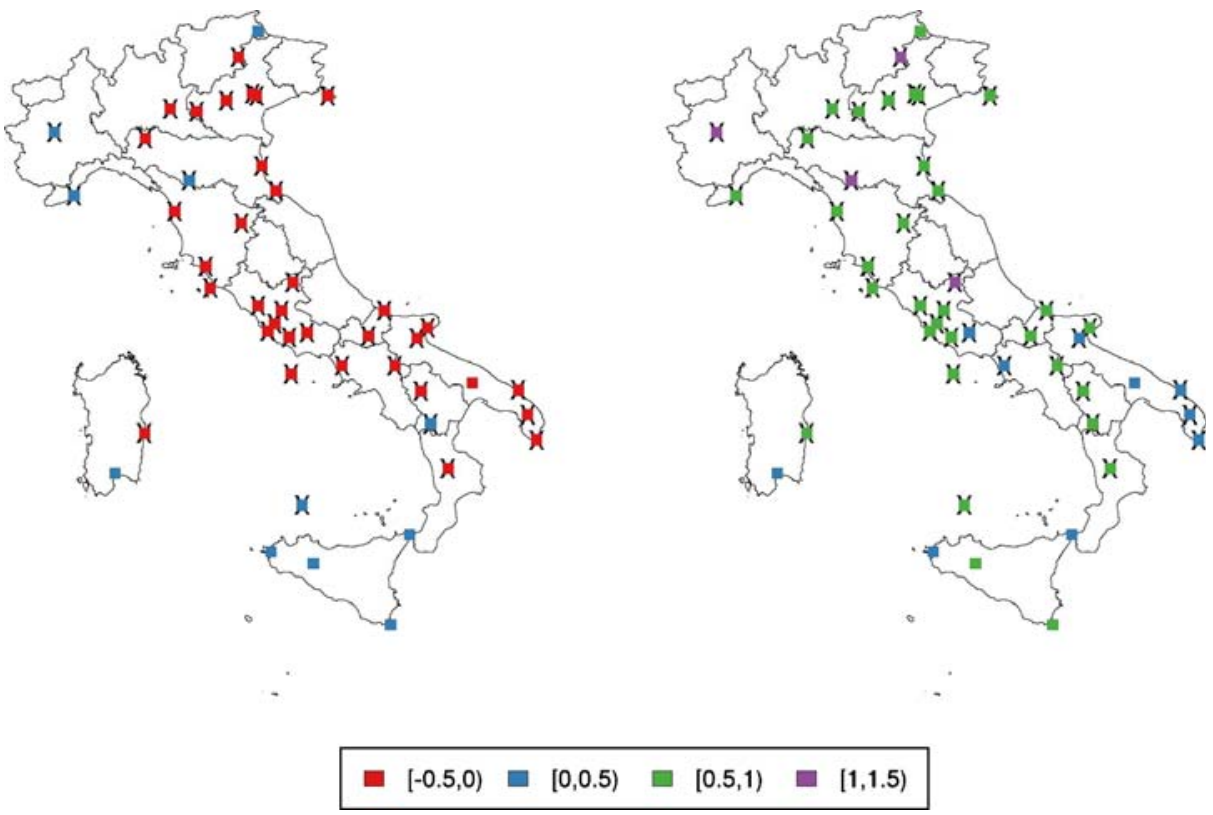

Fig. 11 Spring composites of temperature anomalies for AO indices positive (right panel) and negative (left panel). Crosses denote stations with significant differences

The Scandinavian Pattern index series are correlated with temperature series only during summer and the coefficients are negative (Table 3). Composites of Fig. 10 show the behaviour of temperature anomalies in years with positive and negative SCAN index, because a further subdivision does not provide significant differences. High positive anomalies $\left(>0.5^{\circ} \mathrm{C}\right)$ characterize the panel relative to the negative case; whereas very low anomalies (close to zero) over the whole domain characterize the positive case. Also Xoplaki (2002) found a non-significant correlation in winter; in summer, performing a multi-predictor canonical correlation analysis, a structure of the $300 \mathrm{hPa}$ field (second CCA, well correlated with the temperature field) that reminds the three-center pattern of SCAN was found.

Finally, as for Arctic Oscillation index seasonal series we found a significant correlation with the Northern Italy series in winter and autumn (the same results for winter are presented by Xoplaki 2002), and significant values for all series in spring. Again, spring composites are shown only for positive and negative values of the AO index (Fig. 11).

\section{Discussion and conclusions}

The analysis of Italian seasonal temperatures, elaborated from 1961 to 2006 and recorded at 49 synoptic stations, confirms a general warming, though there are remarkable differences between seasons and geographical areas. Winter series, except the Northern one, are stationary. On the contrary, spring series are characterized by a positive trend for the entire period, with a net increase of about $1.1^{\circ} \mathrm{C}$ for the 
whole domain, although Northern area is characterized by two stationary sub-periods with a sudden change of the mean in 1987. In summer the series resemble annual mean temperature anomaly series (Toreti and Desiato 2008), with a weak cooling trend from 1961 to 1981 (1980 in Central Italy) and a strong warming trend in the following period, that results in a net temperature increase of about $1.5^{\circ} \mathrm{C}$ over the entire domain. All autumn series are stationary until 1970, then they show a positive trend, with a net increase of about $1.6^{\circ} \mathrm{C}$ for Italy as a whole.

Those trends and the differences between seasons need more investigation, in order to understand the processes (behind them) and local factors causing this behaviour.

Concerning the impacts of the detected changes, the winter warming trend in Northern Italy, may have relevant consequences on a sector so vulnerable as winter snow tourism, linked to sport activities, e.g. skiing. For instance, it has been estimated that the number of snow-reliable ski areas in Austria, France, Germany, Switzerland and Italy will be reduced by 100 units if the temperature will rise by $1.2^{\circ} \mathrm{C}$, by 200 with a rise of $2^{\circ} \mathrm{C}$ and by 400 with a rise of $4^{\circ} \mathrm{C}$ (Abegg et al. 2007). The summer tourism will be also influenced by the increase of summer temperature and heat waves events, that will shift the tourism peak towards other seasons (e.g. spring and/or autumn). It is important to underline that those changes will have a strong economic impact, since the Mediterranean area attracts 120 million of visitors (that means about 100 billion of euro; EEA 2008).

As for the relationship with the four chosen teleconnection patterns of Northern Hemisphere, a linear correlation is found with the East Atlantic pattern in all seasons except autumn, with the Scandinavian pattern in summer and with Arctic Oscillation during spring. On the contrary, NAO does not exhibit significant linear correlation with seasonal temperatures, except for northern winter series. These results do not mean the absence of a more complex non-linear relationship between Italian temperature and the low-frequency atmospheric circulation patterns, as highlighted also by composites, that would be worth to investigate more extensively in next studies. An application of a multiple regression model (e.g. Smith and Rose 1991), using only significant correlated indices, gave us the possibility to estimate the explained variance. In winter, values ranges from $31.9 \%$ (for the whole Country) to $40.5 \%$ (for the Northern area; in this case the explained variance was carried out with NAO and EA, leaving out the AO, because it is strongly correlated with NAO). In spring, a model with EA and AO, allowed to carry out values between $38.2 \%$ (Northern Italy) and 50.4\% (Central Italy). Moreover in summer, EA plus SCAN lead to values in $[38.2 \%, 44.7 \%]$. Finally in autumn, the application of a multiple regression model with $\mathrm{AO}$ to series of Northern Italy gives an explained variance equal to $5.7 \%$. These results highlight that a good percentage (except in autumn) of variability can be explained with atmospheric patterns, even if it is very important to underline that local factors have a considerable impact on variability. For example, Fischer et al. (2007) pointed out the role of land-atmosphere interaction in summer heat waves; they found that depletion of soil moisture amplifies summer temperature extremes.

Acknowledgments We are grateful to Dr. Jürg Luterbacher for his suggestions and helpful discussions. We thank Fabiana Baffo for her aid with data. This research was partially supported by the integrated 6th EU framework project CIRCE (Climate Change and Impact Research: the Mediterranean Environment), contract number 036961. 


\section{References}

Abegg B, Agrawala S, Crick F, de Montfalcon A (2007) Climate change impacts and adaptation in winter tourism. In: Agrawala S (ed) Climate change in the European Alps: adapting winter tourism and natural hazards management. Organization for Economic Co-operation and Development, Paris, pp 25-60

Alexandersson H, Moberg A (1997) Homogenization of Swedish temperature data. Int J Climatol 17:25-54

Baccini M, Biggeri A, Accetta G, Kosatsky T, Katsouyanni K, Analitis A, Ross Anderson H, Bisanti L, D'Ippoliti D, Danova J, Forsberg B, Medina S, Paldy A, Rabczenko D, Schindler C, Michelozzi P (2008) Heat effects on mortality in 15 European cities. Epidemiology 19:711-719

Baffo F, Suatoni B, Desiato F (2005) Indicatori climatici: i controlli di validità e la ricerca dei valori errati. Boll Geofis 1, 2:31-41, anno XXVIII

Bai J, Perron P (1998) Estimating and testing linear models with multiple structural changes. Econometrica 66:47-48

Barnston AG, Livezey RE (1987) Classification, seasonality and persistence of low-frequency atmospheric circulation patterns. Mon Weather Rev 115:1083-1126

Brohan P, Kennedy JJ, Harris I, Tett SFB, Jones PD (2006) Uncertainty estimates in regional and global observed temperature changes: a new dataset from 1850. J Geophys Res 111:D12106. doi:10.129/2005JD006548

Brunetti M, Maugeri M, Monti F, Nanni T (2006) Temperature and precipitation variability in Italy in the last two centuries from homogenised instrumental time series. Int J Climatol 26:345-381

Cohen J, Barlow M (2005) The NAO, the AO, and global warming: how closely related? J Climate 18:4498-4513

Desiato F, Lena F, Toreti A (2007) SCIA: a system for a better knowledge of the Italian climate. Boll Geofis Teor Appl 48:351-358

EEA (2008) Impacts of Europe's changing climate-2008 indicator-based assessment. EEA Report $4: 242$

Eischeid JK, Baker CB, Karl TR, Diaz HF (1995) The quality control of long-term climatological data using objective data analysis. J Appl Meteorol 34:2787-2795

Fischer EM, Seneviratne SI, Lüthi D, Schär C (2007) Contribution of land-atmosphere coupling to recent European summer heat waves. Geophys Res Lett 34:L06707. doi:10.1029/2006GL029068

Giraitis L, Leipus R, Philippe A (2006) A test for stationarity versus trend and unit root for a wide class of dependent error. Econom Theory 22:989-1029

Hurrell JW (1995) Decadal trends in the North Atlantic Oscillation: regional temperatures and precipitation. Science 269:676-679

Hurrell JW, Van Loon H (1997) Decadal variations in climate associated with the North Atlantic association. Clim Change 36:301-326

Hurrell JW, Kushnir Y, Visbeck M, Ottersen G (2003) An overview of the North Atlantic Oscillation. The North Atlantic Oscillation: climate significance and environmental impact. Geophys Monogr Series 134:1-35

IPCC (2007) Summary for policymakers. In: Solomon S, Qin D, Manning M, Chen Z, Marquis M, Averyt KB, Tignor M, Miller HL (eds) Climate change 2007: the physical science basis. Contribution of working group I to the forth assessment report of the intergovernmental panel on climate change. Cambridge University Press, Cambridge, United Kingdom and New York, NY, USA

Jones PD, Osborn TJ, Briffa KR (2003) Pressure-based measurements of the North Atlantic Oscillation (NAO). A comparison and an assessment of changes in the strength of the NAO and in its influence on surface climate parameters. In: Hurrell JW, Kushnir Y, Ottersen G, Visbeck M (eds) North Atlantic Oscillation: climatic significance and environmental impacts. Geophysical Monograph vol 134. American Geophysical Union, Washington, pp 51-62

Kostrowicki J (1991) Trends in the transformation of European agriculture. In: Brower FM, Thomas AJ, Chadwick MJ (eds) Land use changes in Europe. The GeoJournal library, vol 18. Kluwer, Dordrecht, pp 21-47

Lund R, Reeves J (2002) Detection of undocumented change points: a revision of the two phase regression model. J Climate 15:2547-2554

Luterbacher J, Dietrich D, Xoplaki E, Grosjean M, Wanner H (2004) European seasonal and annual temperature variability, trends, and extremes since 1500. Science 303:1499-1503

Maracchi G, Sirotenko O, Bindi M (2005) Impacts of present and future climate variability on agriculture and forestry in the temperate regions: Europe. Clim Change 70:117-135 
Peterson T, Easterling D (1994) Creation of homogeneous composite climatological reference series. Int J Climatol 14:671-679

Pires CA, Perdigão RAP (2007) Non-gaussianity and asymmetry of the winter monthly precipitation estimation from NAO. Mon Weather Rev 135:430-448

Pozo-Vázquez D, Esteban-Parra MJ, Rodrigo FS, Castro-Diez Y (2001) A study of NAO variability and its possible non-linear influences on European surface temperature. Clim Dyn 17:701-715

Quadrelli R, Pavan V, Molteni F (2001) Wintertime variability of Mediterranean precipitation and its link with large-scale circulation anomalies. Clim Dyn 17:457-466

Reddaway JM, Bigg GR (1996) Climatic change over the Mediterranean and links to the more general atmospheric circulation. Int J Climatol 16:651-661

Seidel DJ, Lanzante JR (2004) An assessment of three alternatives to linear trends for characterizing global atmospheric temperature changes. J Geophys Res 109(D14):D14108

Shumway RH, Stoffer DS (2000) Time series analysis and its application. Springer, New York, p 549

Smith EP, Rose KA (1991) Trend detection in the presence of covariates: stagewise versus multiple regression. Environmetrics 2:153-168

Smith TM, Reynolds RW (2005) A global merged land and sea surface temperature reconstruction based on historical observations (1880-1997). J Climate 18:2021-2036

Sneyers R (1990) On the statistical analysis of series of observations. In: WMO, Technical Note, vol 143. WMO-415. Geneva, CH, p 192

Thompson DWJ, Wallace JM (1998) The Arctic Oscillation signature in the wintertime geopotential height and temperature fields. Geophys Res Lett 25:1297-1300

Tomé AR, Miranda PMA (2004) Piecewise linear fitting and trend changing points of climate parameters. Geophys Res Lett 31:L02207

Toreti A, Desiato F (2006) Homogenization and validity controls for temperature trend estimation over Italy. In: WMO fifth seminar for homogenization and quality control in climatological databases. Budapest, 29 May-2 June

Toreti A, Desiato F (2008) Temperature trend over Italy from 1961 to 2004. Theor Appl Climatol 91:51-58

Trenberth KE, Jones PD, Ambenje P, Bojariu R, Easterling D, Klein Tank A, Parker D, Rahimzadeh F, Renwick JA, Rusticucci M, Soden B, Zhai P (2007) Observations: surface and atmospheric climate change. In: Solomon S, Qin D, Manning M, Chen Z, Marquis M, Averyt KB, Tignor M, Miller HL (eds) Climate change 2007: the physical science basis. Contribution of working group I to the fourth assessment report. Intergovernmental Panel on Climate Change Cambridge University Press, Cambridge, United Kingdom and New York, NY, USA

Trigo RM, Osborn TJ, Corte-Real JM (2002) The North Atlantic Oscillation influence on Europe: climate impacts and associated physical mechanisms. Clim Res 20:9-17

Vogelsang TJ, Franses PH (2005) Are winters getting warmer? Environ Model Softw 20:1449-1455

Wanner H, Brönnimann S, Casty C, Gyalistras D, Luterbacher J, Schmutz C, Stephenson DB, Xoplaki E (2001) North Atlantic Oscillation - concepts and studies. Surv Geophys 22:321-382

Wibig J (1999) Precipitation in Europe in relation to circulation pattern at $500 \mathrm{hPa}$ level. Int J Climatol 19:253-269

Xoplaki E (2002) Climate variability over the Mediterranean. Ph.D. Thesis, University of Bern, Switzerland

Xoplaki E, Gonzalez-Rouco JF, Luterbacher J, Wanner H (2003) Mediterranean summer air temperature variability and its connection to the large-scale atmospheric circulation and SSTs. Clim Dyn 20:723-739

Xoplaki E, Gonzalez-Rouco JF, Luterbacher J, Wanner H (2004) Wet season Mediterranean precipitation variability: influence of large-scale dynamics and predictability. Clim Dyn 23:63-78 